\title{
Conodont biostratigraphy and depositional history of the Darriwilian (Middle Ordovician) Pygodus serra Zone, western Argentina
}

\author{
*Susana Heredia ${ }^{1}$, Ana Mestre ${ }^{1}$, Cintia Kaufmann ${ }^{1}$, Tatiana Soria ${ }^{1}$ \\ ${ }^{1}$ CONICET-IIM, Facultad de Ingenieria, Universidad Nacional de San Juan. Av. Libertador San Martín 1109 (O), C.P. 5400, \\ San Juan, Argentina. \\ sheredia@unsj.edu.ar; amestre@unsj.edu.ar; ckaufmann@unsj.edu.ar; tsoria@unsj.edu.ar \\ *Corresponding author: sheredia@unsj.edu.ar
}

\begin{abstract}
The stratigraphic record of the Pygodus serra conodont Zone in the Cuyania terrane of western Argentina is discussed in this contribution. Three well-known sections were sampled in Precordillera and the San Rafael Block. The studied successions are composed mainly by clastic rocks with variable amount of carbonate. The lower part of Ponón Trehué Formation of the San Rafael Block and the La Cantera Formation of the Eastern Precordillera are composed of conglomerate and represent the input of coarse clastic deposits to the Cuyania basin. The Los Azules Formation, in Los Amarillitos section of the Central Precordillera, has a massive sandstone bed with carbonate nodules in a section largely of black shale. Key conodonts recovered from these sections indicate a correlation to the E. robustus and E. lindstroemi subzones of the Pygodus serra Zone of the upper Darriwillian Stage (Middle Ordovician Series). The species in the Ponón Trehué Formation are almost all the same as those in the Precordillera sections. Correlation of the clastic sedimentary successions between the three sections indicates that vertical facies changes were not controlled by eustasy. More likely, they were controlled by differential tectonic subsidence.
\end{abstract}

Keywords: Stratigraphy, Ordovician, Pygodus, Cuyania, Precordillera.

RESUMEN. Bioestratigrafía de conodontes e historia depositacional durante el Darriwiliano (Ordovícico Medio), Zona de Pygodus serra, oeste de Argentina. En esta contribución se analiza el registro estratigráfico de la Zona Pygodus serra, subzonas de E. robustus y E. lindstroemi, en Cuyania. Con la finalidad de obtener ejemplares de conodontes se muestrearon tres secciones estratigráficas clásicas en la Precordillera y el Bloque de San Rafael. Las secciones estudiadas se componen principalmente de rocas clásticas con cantidades variables de carbonato. La parte basal de las formaciones Ponón Trehué (San Rafael) y La Cantera (Precordillera) comienzan con conglomerados que representan el ingreso de depósitos clásticos gruesos a la cuenca de Cuyania. La Formación Los Azules (Precordillera), en la sección de Los Amarillitos, exhibe un nivel de arenisca masiva con nódulos de carbonato intercalada con pelitas negras. Los conodontes guías recuperados en estas secciones son similares e indican una correlación con las subzonas de E. robustus y E. lindstroemi, de edad darriwilliana tardía para los estratos portadores. Finalmente, las variaciones verticales de facies, observadas en las sucesiones sedimentarias clásticas estudiadas, son compatibles con un ambiente de sedimentación controlado por una subsidencia tectónica diferencial y no por movimientos eustáticos como había sido propuesto con anterioridad para la cuenca de Cuyania, para este intervalo de tiempo. 


\section{Introduction}

Middle Ordovician outcrops of the Precordillera terrane extend from latitude $29^{\circ} \mathrm{S}$ to $33^{\circ} \mathrm{S}$, and correlative rocks crop out near San Rafael City in the south of Mendoza Province, Western Argentina (Fig. 1). These latter exposures occur in the Sierra Pintada range, in the San Rafael Block of Criado Roqué and Ibáñez (1979), and they are composed of Darriwillian carbonate strata known as the Ponón Trehué Formation (Heredia, 2006). Upper Darriwilian strata have been recognized in the Villicúm range and near Los Cauquenes Dam, Eastern and Central Precordillera respectively, in the San Juan province.

The San Rafael Block as the southern extension of the Precordillera terrane (Fig. 1) has a NNWSSE structural trend. It is $200 \mathrm{~km}$ southwards of the Precordillera in Mendoza Province (Criado Roqué and Ibáñez, 1979). The Cuyo and Neuquén oil basins bound the north and south respectively. Eastwards the San Rafael Block grades into the plains vanishing under the Cenozoic sedimentary cover. To the west, the Frontal Cordillera defines the boundary.

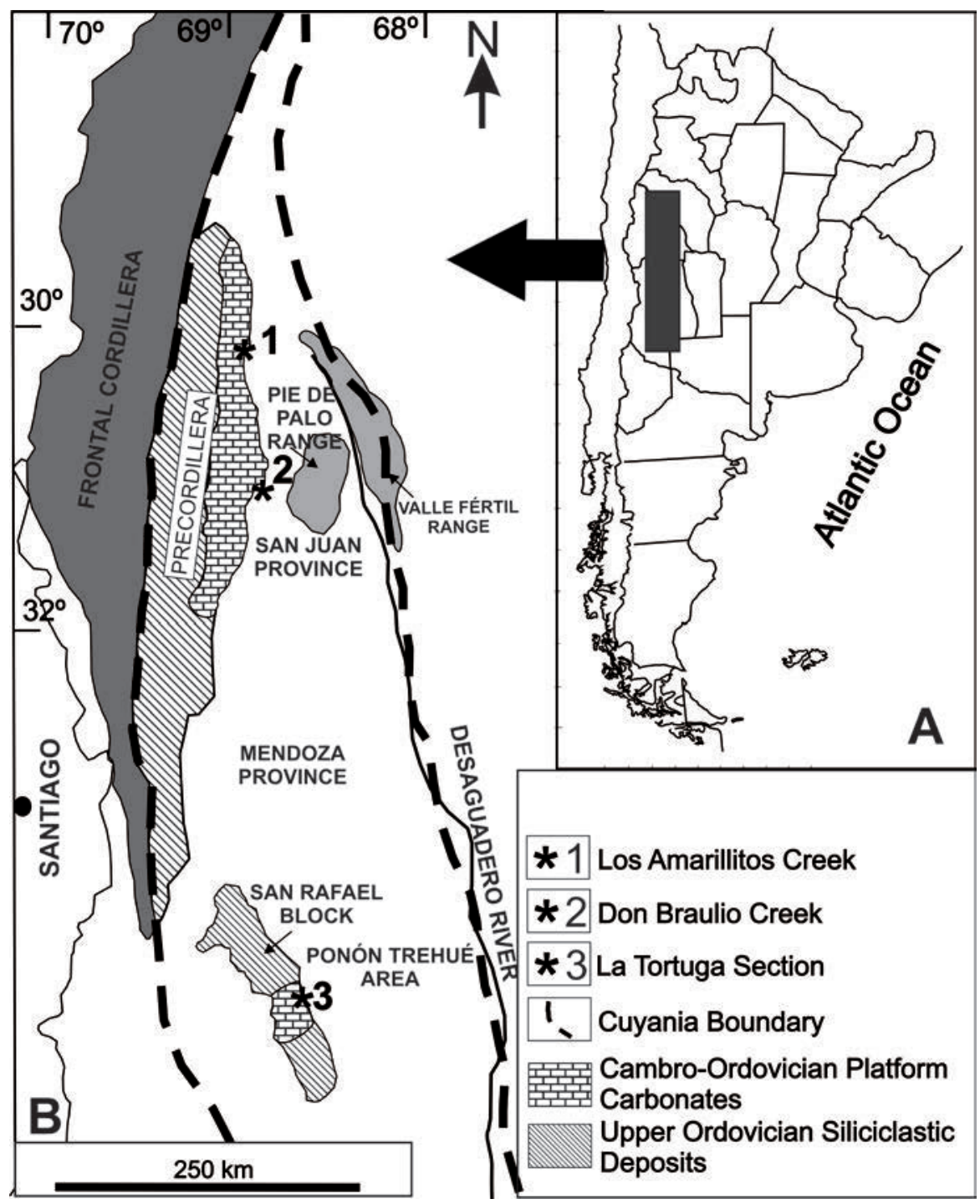

FIG. 1. A. Location map with the study areas. B. Map showing the distribution of Los Amarillitos (1), Don Braulio and La Pola (2), and La Tortuga (3) sections in Cuyania (Argentina) (modified from Heredia et al., 2015). 
The San Rafael Block has diverse igneousmetamorphic and sedimentary successions of Precambrian to middle Paleozoic age, known generally as "pre-Carboniferous units" due to their clear differentiation from the Carboniferous beds by a regional unconformity (Núñez, 1979; González Díaz, 1981). A Greenville-type basement (Ramos et al., 1996; Cingolani and Varela, 1999) is present in the eastern part of the San Rafael Block and is partially covered by the Ponón Trehué Formation, which is composed of fossiliferous carbonate-siliciclastic strata of Ordovician age (Núñez, 1979; Bordonaro et al., 1996; Lehnert et al., 1999; Heredia, 2003 and references mentioned there). Biostratigraphic correlation of these Ordovician strata is based on conodonts, and the correlation of the lower part of the type section of the Ponón Trehué Formation is constrained by the conodont species Eoplacognathus robustus Bergström and Eoplacognathus lindstroemi (Hamar). Both species have been also recovered from the Los Azules Formation and E. robustus is present in the lower part of the La Cantera Formation in the Precordillera basin (Sections 1 and 2 in Fig. 1) (Heredia et al., 2015, 2017).

Heredia et al. (2015) briefly discussed the stratigraphic framework of Cuyania during deposition of strata of the $P$. serra Zone, proposing that eustasy was the primary control on the stratigraphic succession. However, new interpretations of biostratigraphic data allow us to compare the sedimentary successions where the E. robustus and E. lindstroemi subzones (Pygodus serra Zone) are recorded, and on that basis we propose that tectonic subsidence controlled the stratigraphic successions.

\section{Geologic frame}

\subsection{Ponón Trehué region}

The outcrops in the Ponón Trehué area include the only preserved record in all Cuyania of the lower Paleozoic carbonate-siliciclastic succession in depositional contact with basement rocks (Figs. 1 and 2). The basement rocks are late Mesoproterozoic (Grenvillian) (Ramos et al., 1996; Cingolani and Varela, 1999) and constitute the Cerro La Ventana Formation. This formation consists of basic to mesosilicic gneiss, foliated quartz-diorite and tonalite that partially grades to amphibolite and migmatite, and acidic to intermediate granitoid and pegmatitic and aplitic veins.
The outcrops in the Ponón Trehué area (extending in N-S belt $7.5 \mathrm{~km}$ long and up to $2 \mathrm{~km}$ wide) allow for the recognition of three different units. One is composed entirely of the Mesoproterozoic basement. The other two are sedimentary units that include varying amounts of reworked basement rocks. The existence of these various units leads to confusion in the recognition of the proper basement. A wellestablished Ordovician clastic succession of the Ponón Trehué Formation (upper Darriwilian to lower Sandbian) is composed of conglomerate, sandstone and thin-bedded fossiliferous limestone (Fig. 2). The Ponón Trehué Formation records a deepening of the depositional basin. Coarse-grained siliciclastic strata comprise the lower part of the formation, and the upper part consists of dark, fine-grained limestone in thin beds within a succession of black siltstone and shale (Fig. 2). Samples from the limestone beds yielded conodont species indicative of the Pygodus serra and Pygodus anserinus zones (Heredia, 1982; Bordonaro et al., 1996; Heredia, 1996; Lehnert et al., 1999; Heredia, 2001; Cingolani and Heredia, 2001) (Fig. 3). In addition to conodonts, the collections of microfossils include brachiopods, sponge spicules (Beresi and Heredia, 2000), bryozoans, ostracods, crinoids, trilobites and algae.

\subsection{Precordillera}

The Lower-Middle Ordovician carbonate succession of the Precordillera, composed of the La Silla and San Juan formations, crops out along a length of $400 \mathrm{~km} \mathrm{~N}-\mathrm{S}$ with a width of $150 \mathrm{~km}$ $\mathrm{E}-\mathrm{W}$ in the Precordillera. Although this stratigraphic succession reflects the relative stability of platform sedimentation, Middle and Upper Ordovician strata of largely siliciclastic facies exhibit great vertical and lateral heterogeneity that has been taken as a record of tectonic and paleogeographic upheaval. The studied siliciclastic units in this contribution are Los Azules and La Cantera formations that crop out in the Central and Eastern Precordillera, respectively. These formations represent the upheaval in the depositional basin.

The Los Azules Formation (Fig. 2) is based on siliciclastic strata in the Cerro Viejo region, which were studied by several authors such as Borrelo and Gareca (1951), Furque (1979) and Ortega (1987). The former author described the succession as composed by dark claystone and siltstone, black shale, and yellowish calcareous siltstone and marly 
2
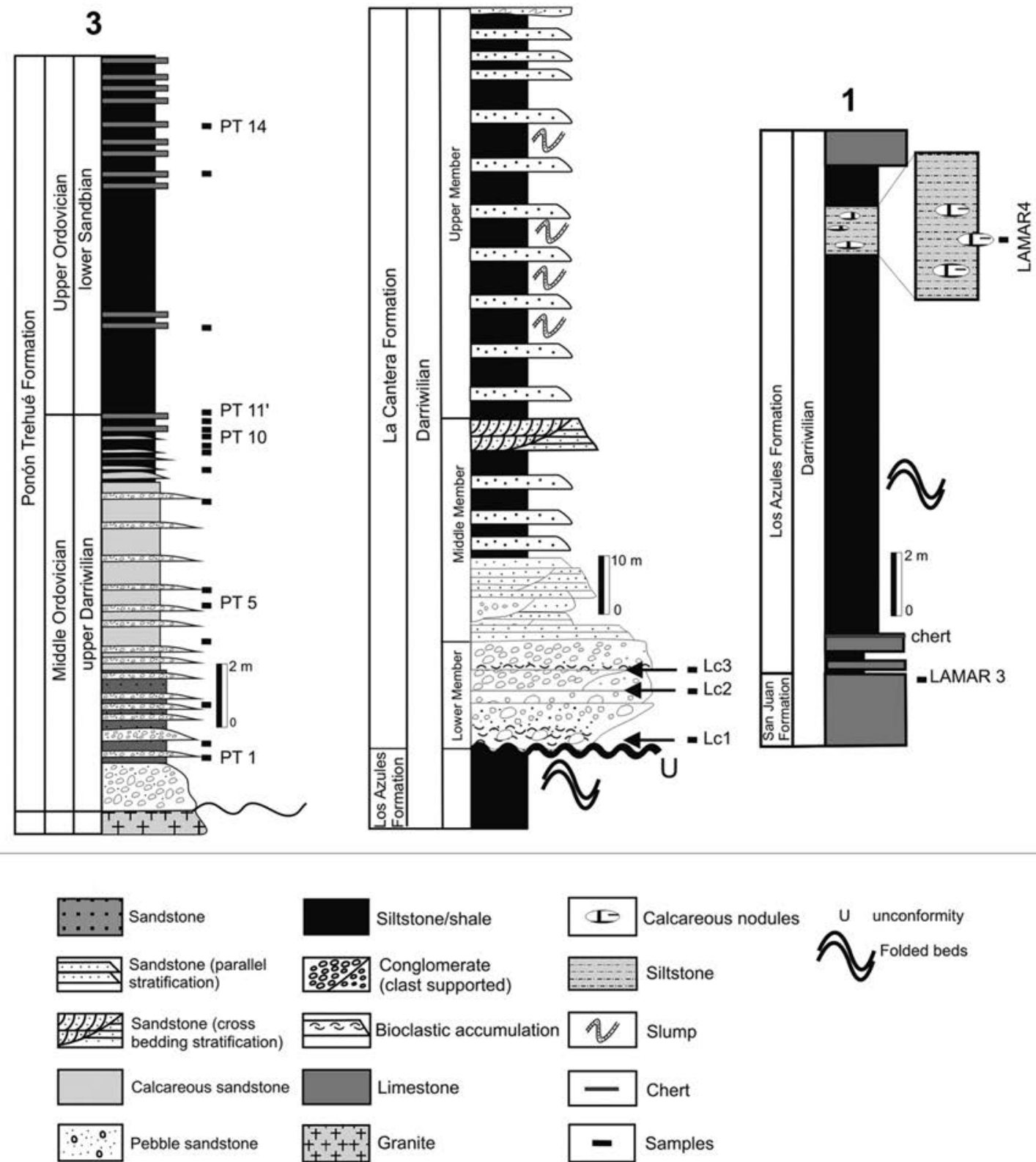

FIG. 2. Stratigraphical columns of studied sections. 1. Los Amarillitos, 2. Don Braulio and 3. La Tortuga sections.

mudstone. A rich graptolite fauna occurs in the Los Azules Formation. In the lower member are recorded the Levisograptus dentatus and Homolograptus lentus zones (lower Darriwilian) (Brussa et al., 2003; Albanesi and Ortega, 2003), the Pterograptus elegans and Hustedograptus teretiusculus zones (upper Darriwilian) occur in the middle member (Ortega and Rickards, 2003; Brussa et al., 2003), and the Climacograptus bicornis Zone associated with conodonts of the Amorphognathus tvaerensis Zone (upper Sandbian) occur in the upper member (Ottone et al., 1999). 
The Los Amarillitos section is located on the western flank of the Cauquenes Range, $4.5 \mathrm{~km}$ west from Cerro Viejo (Figs.1 and 2). There, the San Juan Formation is $330 \mathrm{~m}$ thick (Keller, 1999) and records deposition on a shallow carbonate ramp (Cañas and Aguirre, 2005). In the section, the upper San Juan Formation is composed of nodular, burrowed, bioclastic wackestone-packstone with several hardground surfaces in the uppermost $3 \mathrm{~m}$ where nautiloid phragmacones are abundant (Mestre et al., 2013). The Los Azules Formation overlies the San Juan Formation, and the contact is gradational. It is $209 \mathrm{~m}$ thick and composed by black mudstone, chert and black shale beds alternating in the lower part $(7 \mathrm{~m})$ overlain by folded black shale that is overlain, in turn, by a two-meter thick bed of yellowish massive fine-grained sandstone $(2 \mathrm{~m})$ with carbonate nodules. The sandstone bed is overlain by $200 \mathrm{~m}$ of yellowish calcareous siltstone and marly mudstone (Fig. 2).

The La Cantera Formation, redefined by Baldis et al. (1982), is a siliciclastic unit that crops out in the Villicúm Range of the Eastern Precordillera (Ortiz and Zambrano, 1981). It overlies the Los Azules Formation, and it is unconformably overlain by Hirnantian diamictites of Don Braulio Formation. The La Cantera Formation is composed of about $142 \mathrm{~m}$ of greenish, fining-thinning upward siliciclastic strata with graptolites of the Hustedograptus teretiusculus and Nemagraptus gracilis zones (Peralta, 1993), which correlate with the upper Middle to lower Upper Ordovician. This formation is composed of three members (Peralta, 1993). The lower member is recognized in Don Braulio creek (Fig. 1) and La Pola creek and differs between them. This member at $\mathrm{La}$ Pola section includes green shales with graptolites and conodonts indicating the Eoplacognathus suecicus Zone, Pygodus anitae Subzone (see Heredia et al., 2014) followed by conglomerate beds, while Don Braulio section is composed mainly by brown sandstone and conglomerate, which are interbedded with pebbly sandstone and siltstone. Brachiopods, conodonts, gastropods, and trilobites were recovered from these brown sandstone beds in lowermost part of the formation.

The middle member is composed by fossiliferous shale and sandstone with brachiopods, bryozoans and scarce ichnofossils belonging to the Cruziana ichnofacies (Peralta, 1993). The upper member of the La Cantera Formation is a finning-thinning upward succession with extensive synsedimentary deformation (Fig. 2).

\section{Conodonts}

Well preserved specimens of conodonts were recovered from carbonate, carbonate nodule and carbonate-sandstone samples from the Ponón Trehué, Las Azules, and La Cantera formations (Figs. 2, 3). Specimens from La Cantera Formation are represented only by $\mathrm{P}$ elements recovered from Don Braulio section.

The Ponón Trehué Formation was sampled through $25 \mathrm{~m}$. Samples were collected from conglomerate, from sandstone beds with fossiliferous carbonate layers, and from sandstone beds with carbonate cement. Many specimens of Eoplacognathus robustus Bergström and Eoplacognathus lindstroemi (Hamar) were recovered, respectively, from samples PT3 to PT10 and samples PT10 to PT11' (Figs. 2, 3).

The index conodont E. robustus was found in fossiliferous sandstone beds at the base of the conglomerate of the lower member of La Cantera Formation (Heredia et al., 2014) (Figs. 2, 3).

Few and well preserved elements of $E$. robustus together with early forms of $E$. lindstroemi and $P$. serra were recovered from the Los Azules Formation in Los Amarillitos section, from carbonate nodules in the black siltstone and fine sandstone beds (Figs. 2, 3).

Five hundred seventeen $\mathrm{P}$ elements of Eoplacognathus were retrieved from these sections. Although illustrated here (Fig. 3), these specimens of $E$. robustus and E. lindstroemi are already well known and described and thus are not described here.

All photographic illustrations (Fig. 3) are SEM digital photomicrographs. The illustrated elements are housed in collections of the Museo de Paleontología (Universidad Nacional de Córdoba) under the code CORD-MP, and the INGEO at Universidad Nacional de San Juan under the code INGEO-MP.

\section{Conodont biostratigraphy}

The conodont species E. robustus and an early form of $E$. lindstroemi characterize the E. robustus and E. lindstroemi subzones of the Pygodus serra Zone. An advanced form of E. lindstroemi (Fig. 4) ranges into the overlying $P$. anserinus Zone (Bergström, 1971). The species E. robustus is constrained to the homonymous subzone and to the lowermost part of the E. lindstroemi subzone (Heredia, 2003). Several elements identified as transitional forms between $E$. robustus and E. lindstroemi were recovered 


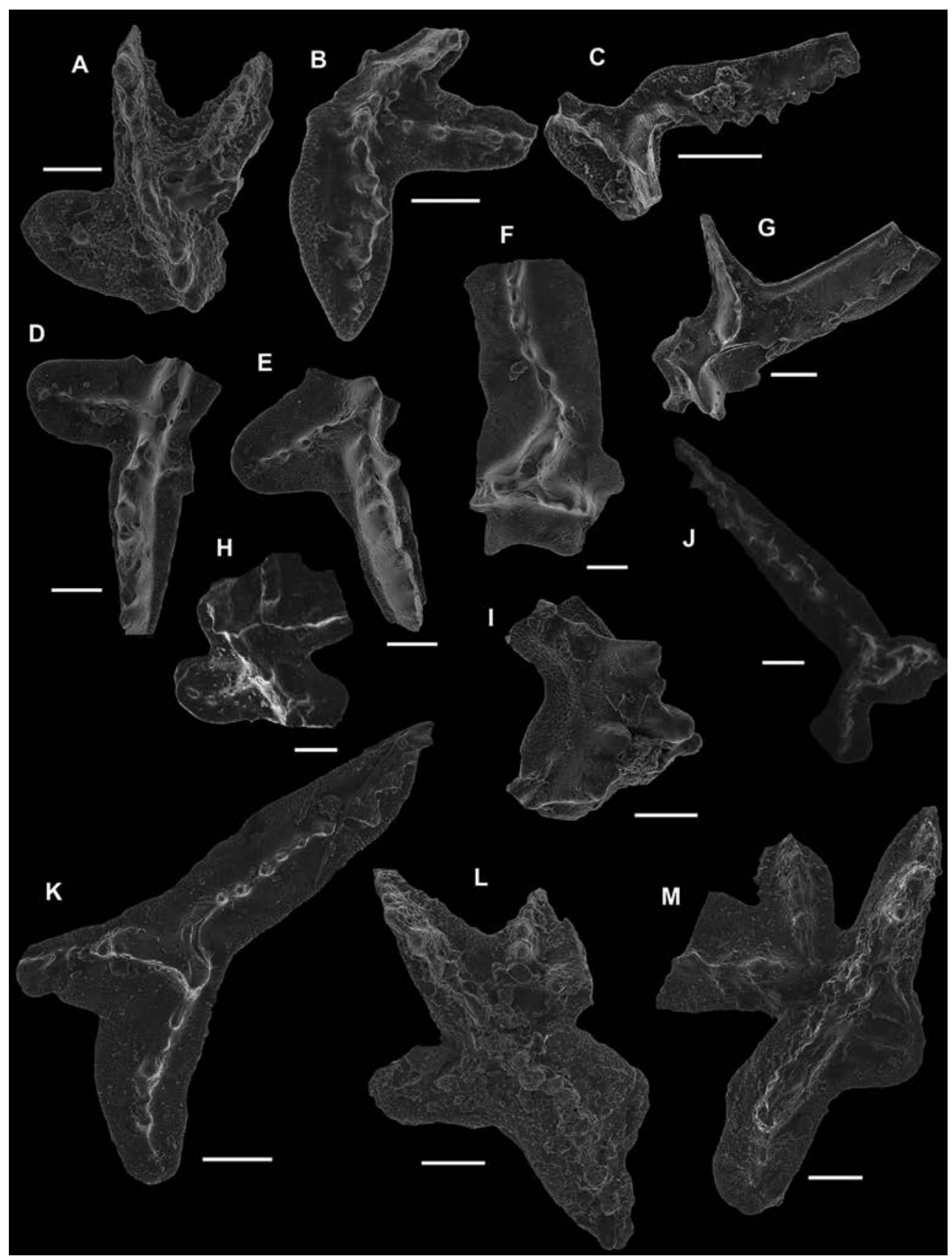

FIG. 3. Plate Microphotographs of scanning electron microscope. The scale bar indicates $0,1 \mathrm{~mm}$ : Scanning electron microscope photomicrographs. A, C Eoplacognathus robustus Bergström: A. dextral Pa element, oral view, INGEO MP 2000 (1), Los Amarillitos section, LAMAR 4; C. dextral Pb element, oral view, INGEO MP 2000 (2), Los Amarillitos section, LAMAR 4. B. Eoplacognathus lindstroemi (Hamar), sinistral Pa element, oral view, INGEO MP 2001 (1), Los Amarillitos section, LAMAR 4. D-G. Eoplacognathus robustus Bergström: D,E,G. dextral Pa element, oral views, INGEO MP 3600 (1,2,3), Don Braulio section, Lc2. F. sinistral Pb element, oral view, INGEO MP 3600 (4), Don Braulio section, Lc2. H-K. 13, Eoplacognathus robustus Bergström, La Tortuga section. H. dextral Pa element, oral view, CORD MP 2228 (1), PT 8. I. dextral Pb element, oral view, CORD MP 2229 (5), PT9. J. sinistral Pb, oral view, CORD MP 2229(1) PT9. K. dextral Pb element, oral view, CORD MP 2223 (5), PT 9. L. Eoplacognathus robustus-E.lindstroemi transition, dextral Pa element, oral view, CORD MP 2269 (2), La Tortuga section, PT 10. M. sinistral Pa element, oral view, CORD MP 2225 (1), PT 9. 


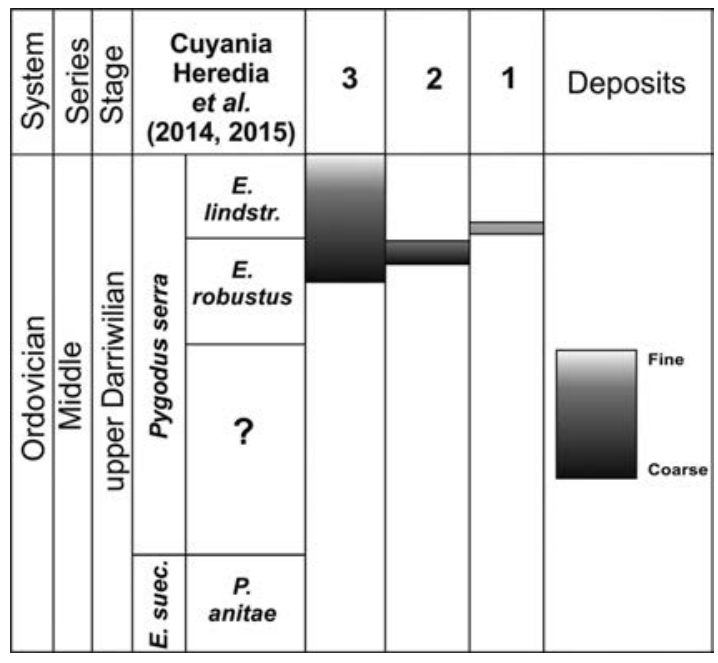

FIG. 4. Cuyanian conodont biozone chart for the upper Pygodus serra Zone. Notice the probable intervals of the Eoplacognathus robustus and Eoplacognathus lindstroemi subzones recorded in the studied outcrops in Cuyania. 1. Los Amarillitos, 2. Don Braulio and 3. La Tortuga sections (adapted from Heredia et al., 2015).

from sample PT10 in the Ponón Trehué section indicating the evolutionary link between these two index conodonts (Heredia, 2003).

Bergström (1971) described and named the species E. suecicus, E. foliaceous, E. reclinatus, E. robustus, E. lindstroemi and E. elongatus, and documented their stratigraphic distribution in several sections of Sweden. They were considered indicative of the Baltic province and are recorded from localities around the world: USA (Alabama, Tennessee, Nevada, Virginia, and New York), Estonia, Wales, Ireland, China and Argentina (Bergström, 1971; Viira, 1974, 2011; Heredia, 2003).

Zhang (1998) re-studied these species proposing changes in their interpretation and recognizing the genera Baltoplacognathus, Yangtzeplacognathus and Eoplacognathus. The index species Yangtzeplacognathus foliaceous, Baltoplacognathus reclinatus, $B$. robustus, E. lindstroemi and E. elongates were redefined among others. This author supported this proposal based on the morphological features of the $\mathrm{Pa}$ elements (Baltoplacognathus) or $\mathrm{Pb}$ elements (Yangtzeplacognathus), linking them discontinuously. The specimens in our collection illustrate the close morphological similarity of E. robustus and $E$. lindstroemi, and allows us to conclude that E. lindstroemi is the direct descendent of E. robustus.
Accordingly, we follow the nomenclature and species concepts of Bergström $(1971,1983)$.

\section{Depositional history of strata of the P. serra Zone in Cuyania}

The La Cantera and Ponón Trehué formations are composed of coarse siliciclastic strata overlain by finer siliciclastic strata. The conglomerate of the base of the La Cantera Formation has an erosive, unconformable contact with the underlying Los Azules Formation. The fine green shale of the La Cantera Formation at La Pola section (see Heredia et al., 2014) paraconformably overlies the Los Azules Formation. These successions indicate a change in the depositional basin from fine-grained, low energy sedimentation to coarser-grained, higher energy sedimentation. This coarse facies indicates renewed transgression following an erosive event (probably during the E. foliaceous-E. reclinatus subzones).

In Los Amarillitos section the co-occurrence of $E$. robustus and early E. lindstroemi indicates the lowermost E. lindstroemi Subzone (Fig. 4). The stratigraphic interval is composed of black shale and fine-grained sandstone with carbonate nodules and black carbonate mudstone, deposited in a deep and relativity low energy environment similar to the deposition environment interpreted for the upper part of the Ponón Trehué Formation, which also is composed of black mudstone and fine-grained sandstone (Fig. 4). We conclude that the strata of the E. lindstroemi Subzone represent a deepening of the depositional basin. The question is whether it results from a eustatic sea-level rise or tectonic subsidence.

Nielsen (2011) proposed sea-level curves for the Ordovician Period in Baltoscandia that are also recognized on most paleocontinents. However, the shallowing and deepening events in our sections do not match those of the Baltic curves (Fig. 5). In contrast to high sea-level worldwide at the base of the P. serra Zone, correlative facies in our sections indicate sea-level lowstand and even exposure and erosion. The interval of the E. lindstroemi Subzone records a sea-level rise and highstand, while the global sea-level curve indicates a rapid sea-level fall. During the $P$. anserinus Zone both basins exhibit deposits that represent a high sea-level indicated by the carbonate shaly facies of Las Aguaditas Formation (Las Aguaditas Creek) and the upper 


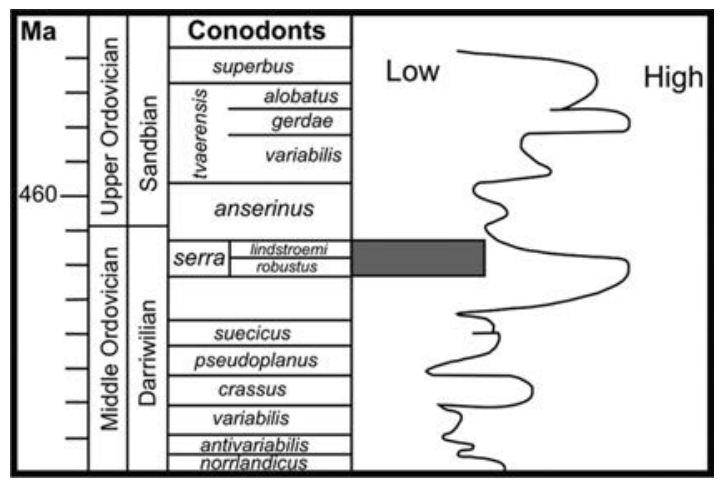

FIG. 5. Biozone chart and its relationship with sea level curves during the Middle-Upper Ordovician and comparison with the Cuyania records (adapted from Nielsen, 2011).

member of Los Azules Formation. Comparing the facies of these three studied sections with the global sea level-curves proposed by Nielsen (2011) we conclude that eustacy did not control sedimentation in Cuyania for this time interval. Therefore, we conclude that the stratigraphic successions in our sections record tectonic subsidence. We also interpret that this sedimentary arrangement indicates an inland uplift and an active clastic continental input but a low sedimentary basin accommodation.

\section{Acknowledgements}

The authors thank to the PIP 139 grant (Research National Council of Argentina). Technician M. González is acknowledged for her work at conodont lab. The MEByM from the CCT-Mendoza is thanked for the SEM microphotographs. We are grateful to Dr. S.C. Finney for his geological revision and substantial improvements on the English language and to Dr. J. Carlorosi for her comments that improved the manuscript.

\section{References}

Albanesi, G.; Ortega, G. 2003. Advances on ConodontGraptolite Biostratigraphy of the Ordovician System of Argentina. In Aspects of Ordovician System in Argentina (Aceñolaza, F.G.; editor). Serie Correlación Geológica 16, INSUGEO 143-166. Tucumán.

Baldis, B.A.; Beresi, M.S.; Bordonaro, O.; Vaca, A. 1982. Síntesis evolutiva de la Precordillera argentina. In Congreso Latinoamericano de Geología, No. 5, Actas 4: 399-445. Buenos Aires.
Beresi, M.; Heredia, S. 2000. Sponge spicule assemblages from the Middle Ordovician of Ponón Trehué, Southern Mendoza, Argentina. Revista Española de Paleontología 15: 37-48.

Bergström, S.M. 1971. Conodont Biostratigraphy of the Middle and Upper Ordovician of Europe and eastern North America. In Symposium on Conodont biostratigraphy (Sweet, W.C.; Bergström, S.M.; editors). Geological Society of America Memory 127: 83-157.

Bergström, S. 1983. Biogeography, evolutionary relationships and biostratigraphic significance of Ordovician platform conodonts. Fossils and Strata 15: 35-58.

Bordonaro, O.; Keller, M.; Lehnert, O. 1996. El Ordovícico de Ponón Trehué en la Provincia de Mendoza (Argentina): Redefiniciones estratigráficas. In Congreso Geológico Argentino, No. 13 y Congreso de Exploración de Hidrocarburos, No. 3, Actas 1: 541-550. Buenos Aires.

Borrelo, A.V.; Gareca, P.G. 1951. Sobre la presencia de Nemagraptus gracilis (Hall) en el Ordovícico del Norte de San Juan. Revista de la Asociación Geológica Argentina 6: 187-193.

Brussa, E.D.; Mitchell, C.E.; Ortega, G.; Maletz, J.; Astini, R.A. 2003. Middle Ordovician graptolite biostratigraphy from the Los Azules Formation at Los Gatos creek, Central Precordillera, Argentina. In Proceedings of the International Graptolite Conference, No. 7 (Ortega, G.; Aceñolaza, G.F.; editors). Serie de Correlación Geológica, 18, INSUGEO: 21-32. Tucumán.

Cañas, F.L.; Aguirre, H. 2005. Estratigrafía de alta resolución de la Formación San Juan (Ordovícico inferior de la Precordillera de Cuyo, San Juan, Argentina): Resultados preliminares. In Congreso Geológico Argentino, No. 16, Actas 3: 365-370. La Plata.

Cingolani, C.; Varela, R. 1999. The San Rafael Block, Mendoza (Argentina): Rb-Sr Isotopic age of basement rocks. In South American Symposium on Isotope Geology, No. 2, Actas: 23-26. Córdoba.

Cingolani, C.; Heredia, S. 2001. The Ordovician of Mendoza. Field Trip Guide, International Symposium on the Ordovician System, INSUGEO, Serie Miscelánea 7: $37 \mathrm{p}$.

Criado Roqué, P.; Ibáñez, G. 1979. Provincia geológica Sanrafaelino-pampeana. In Simposio de Geología Regional Argentina, No. 2, Academia Nacional de Ciencias 1: 837-869. Córdoba.

Furque, G. 1979. Descripción Geológica de la Hoja 18c, Jáchal, Provincia de San Juan. Boletín Servicio Geológico Nacional 164: 1-85. 
González Díaz, E.F. 1981. Nuevos argumentos a favor del desdoblamiento de la denominada "Serie la Horqueta", del Bloque de San Rafael, provincia de Mendoza. In Congreso Geológico Argentino, No. 8, Actas 3: 241-256. San Luis.

Heredia, S. 1982. Pygodus anserinus Lamont et Lindström (Conodonto) en el Llandeillano de la Formación Ponón Trehué. Ameghiniana 19: 101-104.

Heredia, S. 1996. El Ordovícico del Arroyo Ponón Trehué, sur de la provincia de Mendoza. In Congreso Geológico Argentino, No. 13 y Congreso de Exploración de Hidrocarburos, No. 3, Actas 1: 601-605. Buenos Aires.

Heredia, S. 2001. Late Llanvirn conodonts from Ponón Treuhué Formation, Mendoza, Argentina. Gaia 16: 101-117.

Heredia, S. 2003. Upper Llanvirn-Lower Caradoc conodont biostratigraphy, Southern Mendoza, Argentina. In Aspects of the Ordovician System in Argentina (Aceñolaza, F.G.; editor). INSUGEO, Serie Correlación Geológica 16: 167-176. Tucumán.

Heredia, S. 2006. Revisión estratigráfica de la Formación Ponón Trehué (Ordovícico), Bloque de San Rafael, Mendoza. INSUGEO Serie Correlación Geológica 21: $59-74$.

Heredia, S.; Mestre, A.; Soria, T.; Kaufmann, C. 2015. The Ordovician Pygodus serra Zone in Cuyania, Argentina. Stratigraphy 12 (2): 37-39.

Heredia, S.; Mestre, A.; Soria, T.; Kaufmann, C. 2017. The Ordovician genus Pygodus (conodont) in the Cuyania Terrane, Argentina. Geological Magazine 154 (5): 1105-1116.

Heredia, S.; Kaufmann, C.; Mestre, A.; Soria, T.; Ortega, G. 2014. La edad de la base de la Formación La Cantera (Ordovícico) en la Precordillera Oriental, Sierra de Villicum, San Juan. In Congreso Geológico Argentino, No. 19: S2-13. Córdoba.

Keller, M. 1999. Argentine Precordillera: Sedimentary and Plate Tectonic History of a Laurentian Crustal Fragment in South America. Geological Society of America, Special Paper 341: 1-131.

Lehnert, O.; Bergström, S.; Keller, M.; Bordonaro, O. 1999. Middle Ordovician (Darriwillian-Caradocian) conodonts from the San Rafael region, west-central Argentina: Biostratigraphic, paleoecologic and paleogeographic implications. Bolletino Della Societá Paleontologica Italiana 37: 199-214.

Mestre, A.; Beresi, M.; Heredia, S. 2013. Nautiloid cephalopod concentration beds in the San Juan Formation (middle Darriwilian) of the Argentine Precordillera. In Conodont from the Andes (Albanesi, G.; Ortega, G.; editors).
Asociación Paleontológica Argentina, Publicación Especial 13:73-78.

Nielsen, A.T. 2011. A re-calibrated revised sea-level curve for the Ordovician of Baltoscandia. In Ordovician of the World (Gutiérrez-Marco, J.C.; Rábano, I.; GarcíaBellido, D.; editors). Instituto Geológico y Minero de España: 399-402.

Núñez, E. 1979. Descripción Geológica de la Hoja 28d, estación Soitué. Provincia de Mendoza. Servicio Geológico Nacional, Boletín 166: 1-67.

Ortega, G. 1987. Las graptofaunas y conodontes de la Formación Los Azules, Cerro Viejo, zona de Huaco, Departamento Jáchal, San Juan. Ph.D. Thesis (Inédito), Facultad de Ciencias Exactas, Físicas y Naturales, Universidad Nacional de Córdoba: 210 p.

Ortega, G.; Rickards, R.B. 2003. A Darriwilian (Middle Ordovician) graptolite fauna of the lower member of the Los Azules Formation, Cerro Viejo, San Juan Precordillera, Argentina. In Proceedings of the International Graptolite Conference, No. 7 (Ortega, G.; Aceñolaza, G.F.; editors). Serie de Correlación Geológica 18, INSUGEO: 87-95. Tucumán.

Ortiz, A.; Zambrano, J. 1981. La provincia geológica Precordillera Oriental. In Congreso Geológico Argentino, No. 8, Actas: 9-74. San Luis.

Ottone, E.G.; Albanesi, G.; Ortega, G.; Holfeltz, G.D. 1999. Palynomorphs, conodonts and associated graptolites from the Ordovician Los Azules Formation, Central Precordillera, Argentina. Micropaleontology 45: 225-250.

Peralta, S.H. 1993. Estratigrafía y consideraciones paleoambientales de los depósitos marino clásticos eopaleozoicos de la Precordillera Oriental de San Juan. In Congreso Geológico Argentino, No. 12 y Congreso de Exploración de Hidrocarburos, No. 2: 128-137. Mendoza.

Ramos, V.A.; Vujovich, G.I.; Dallmeyer, R.D. 1996. Los klippes y ventanas tectónicas preándicas de la Sierra de Pie de Palo (San Juan): edad e implicaciones tectónicas. In Congreso Geológico Argentino No. 13 y Congreso de Exploración de Hidrocarburos, No. 3, Actas 5: 377-391. Buenos Aires.

Viira, V. 1974. Ordovician Conodonts of the East Baltic. Valgus Publishers, Tallinn: 142 p. [in Russian, with English summary].

Viira, V. 2011. Lower and Middle Ordovician conodonts from the subsurface of SE Estonia and adjacent Russia. Estonian Journal of Earth Sciences 60: 1-21.

Zhang, J.H. 1998. Middle Ordovician conodonts from the Atlantic Faunal Region and the evolution of key conodont genera. Meddelandenfrån Stockholms Universitets institution förgeologiochgeokemi 298: 5-27. 